\title{
COVID-19 and Japanese shareholder activism: brief respite for Japan's self-healing concrete
}

\author{
Toru Yoshikawa ${ }^{1} \cdot$ Gavin Chua $^{2}$
}

Published online: 22 May 2020

(c) Springer Nature Limited 2020

\begin{abstract}
Extrapolating from modern international understanding of corporate Japan's distinct form of managerial capitalism, we elaborate on the growing momentum of shareholder activism in Japan leading up to the COVID-19 health crisis, so as to inform the subsequent discussion on the relevant primary considerations that belie the future direction of shareholder activism in Japan post-COVID-19. On an initial logical extrapolation, it appears probable that COVID-19 could mark the peak of Japanese activism. However, it is crucial to acknowledge that the success of Japan's managerial capitalism have also declined, which poses a question on to which direction Japanese corporate governance may be shifting. Finally, we point out how corporate Japan's impeding market developments will provide a useful case-study for global financial discourse.
\end{abstract}

Keywords Japanese firms · Shareholder activism · Corporate governance · Stakeholder model $\cdot$ COVID-19

\section{Introduction}

The COVID-19 health crisis has catalyzed a demand-side, real economy-led economic downturn, throwing financial markets around the world into a period of considerable uncertainty and volatility. Equity capital markets are not exempt, and shareholder activists' ability to shrewdly navigate the turbulent storm will be tested. We canvas the corporate terrain leading up to the COVID-19 health crisis, and then present some considerations from both the outside investor's perspective and the corporate insider's perspective. Finally, we discuss a possible direction of

Toru Yoshikawa

toru@smu.edu.sg

1 Lee Kong Chian School of Business, Singapore Management University, Singapore, Singapore

2 School of Law, Singapore Management University, Singapore, Singapore 
shareholder activism in Japan and the future Japanese market-sensitivity to international corporate governance norms.

\section{Pre-COVID-19 shareholder activism expansion}

Prior to COVID-19, there was an almost unanimous acknowledgement of the tremendous momentum behind shareholder activism (both confrontational and quiet), as an expression of shareholder primacy, in Japan (Buchanan et al. 2012). This is unsurprising given the abundance of public companies with solid performance, undervalued stock prices, excess cash reserves, vulnerable capital policies and often insulated management. In 2019, Japan was the most-targeted non-US jurisdiction, with local records of 19 activist campaigns, $\$ 4.5$ billion in capital deployed, 58 public companies targeted, 22 shareholder demands for board representation and 14 proxy fights (Activist Insight 2020).

As observed by many researchers (e.g., Ahmadjian and Robins 2005; Yoshikawa and McGuire 2008), incremental convergence between Japan's insider or stakeholder-oriented corporate governance system and Anglo-American shareholder-centric model had been occurring slowly but surely, partially catalyzed by the bubble economy collapse and the globalization of capital markets. Per the reflexive nature of market development, the growing success of early shareholder activists, coupled with attendant legal and regulatory developments, laid the groundwork for the current boom in Japanese shareholder activism, prominently led by Paul Singer's Elliott Management, Daniel Loeb's Third Point Management and Yoshiaki Murakamirelated parties. The movement was further buttressed by Prime Minister Shinzo Abe's corporate governance reform initiatives through the Stewardship Code and Corporate Governance Code. Nonetheless, certain crucial structural impediments remained, pushing back against complete convergence.

First, the complex corporate governance situation stemming from Japanese firms' unique capital structures must be appreciated. A byproduct of its war-era, bankbased economy, cross-shareholdings among affiliated firms meant that a portion of a public company's shares would be held by the company's banks, customers, suppliers, and other friendly partners. This leads to a structural conflict of interest, since such stable shareholders wearing two hats would often prioritize ongoing business relationships and stable business ties over high investment returns, decreasing pressure on firm's profit performance and cash returns (via dividends or share buybacks) and reinforcing managerial independence (Yoshikawa and McGuire 2008).

Second, as discussed by many observers (e.g., Ahmadjian and Robins 2005), group-focused loyalties and identities persist in corporate Japan's mental universe, leading to a stakeholder-oriented model. Though cracks had begun to emerge with the increasing acceptance of shareholder value maximization rhetoric, certain setbacks to the activist momentum (e.g., Murakami's 2006 arrest for insider trading) potentially offered a rare glimpse into Japan, Inc.'s closing ranks. This cultural bias has translated into a practical constrain on the usual activist strategies seen in more divisive equity capital markets like the US. 
Thus, pre-COVID-19, corporate Japan was undergoing a transitionary period that was potentially a crucial determinant of Japan's future corporate governance norms.

\section{Post-COVID-19 managerial capitalism resurgence?}

The COVID-19 health crisis could not have come at a worse time. Deep-rooted cultural change requires time for truly lasting cracks to cement, and this pandemic-catalyzed economic downturn looks to stop the winds in the activists' sails. Momentum, once lost, can be hard to regain.

No doubt, for certain ongoing high-stake corporate tussles (e.g., Softbank and Elliott Management), the concurrent decline in real economy performance and liquidity will bring tensions to a head. But for the vast majority of activist actions, the heightened volatility and economic uncertainty will pose drastic challenges (Gottfried and Donahue 2020), notwithstanding increased opportunities from lowered valuations (TOPIX 500 plunged $31 \%$ from 52-week highs, similar to S\&P 500 's $35 \%$ plunge from 52-week highs) and potential target firm vulnerability due to relatively weaker shareholder rights plans (Koh et al. 2019).

First, the inherent nature of this real economy-led economic downturn means that firm preservation, not shareholder value maximization (since cash distributions adversely impact a firm's liquidity), will be at the forefront of companies' peripheries. Japan's unique capital structure of cross-shareholdings and stable shareholdings will only exacerbate such concerns, since a proportion of the listed company's shareholders will have the exact same skin in the game. Therefore, such conflicted shareholders may lend immediate managerial support now, in hopes that it may lead to reciprocal support. As such, shareholder activists may soon find that the support they can count on (e.g., domestic institutions) in proxy fights are now diminished during this period, as management distraction concerns and further instability exacerbation outweigh any potential benefits. Second, on the ideological front, usual activists' inefficiency arguments against cash-hoarders during prosperous times will now be poignantly countered with the raw experience of resiliency during these turbulent times (Lewis 2020).

\section{Conclusion}

On a micro-scale, there is no doubt that COVID-19 has the real potential to represent the inflection point for shareholder activism in Japan, as market mood turns against corporate outsiders. But whether this subsequently manifests in reality depends much on the surrounding circumstances that prevail long past COVID-19. First, given the fact that the Japanese market has long matured, and growth opportunities are increasingly scarce, the viability and sustainability of Japan's managerial capitalism may simply no longer hold true. Capital inefficiency due to managerial preference to lock in capital within the firm will generate ever-increasing agency costs. Second, the post-war-era agency cost hedges no longer operate to the same extent. For example, the economic incentive systems (lifetime employment, seniority-based wages) designed to align managerial interests within the company have eroded over time (Yoshikawa and McGuire - 
2008), coupled with ever-increasing reliance on temporary workers, as a creative adaptation of Japan's existing employment institutions, to cope with greater market pressures. Thus, the short-term inefficiencies of managerial capitalism may no longer produce long-term economic growth (to the same extent) given the modern circumstances of Japan's economy.

On a macro-scale, the corporate discussions to follow provide an interesting casestudy for global discourse. The current hot potato in the financial realm surrounds the proper primary purpose of a company: should it be a purely profit-seeking private entity or should it resemble quasi-public entities focused on broader stakeholder considerations and thus indirectly, economic growth? The COVID-19 aftermath will produce unique invaluable research domain to better discern the resiliency of Japan's stakeholder-model economy (e.g., the number of Japanese corporate insolvencies vis-àvis the U.S.) and thus contribute to discussions on comparative corporate governance. On a glass half-full approach, one could even posit that the timing of this black swan event could not be better, as the arguments for both potential points on the Pareto frontier can now be discussed adequately and frankly before significant transitionary costs are incurred as Japan (and many other economies) may be further shifting to a marketbased, shareholder-oriented model. After all, there is no universal method for economic efficiency, and much stems from strategies tailored to a countries' current comparative institutional advantages.

\section{References}

Activist Insight. 2020. The activist investing annual review. Accessed from https://www.activistinsight.com/.

Ahmadjian, C. L., \& Robbins, G. E. (1990s). A Clash of capitalism: Foreign shareholders and corporate restructuring in 1990s Japan. American Sociological Review, 70(3), 451-471.

Buchanan, J., Chai, D. H., \& Deakin, S. (2012). Hedge fund activism in Japan: The limits of shareholder primacy. Cambridge: Cambridge University Press.

Gottfried, K., and S. Donahue. 2020. The impact of COVID19 on shareholder activism. Harvard Law School Forum on Corporate Governance. Accessed from https://corpgov.law.harvard.edu/2020/04/12/theimpact-of-covid19-on-shareholder-activism/.

Koh, A., M. Nakahigashi, and D. Puchniak. 2019. Land of the falling 'poison' pill: Understanding defensive measures in Japan on their own terms. NUS Law Working Paper No. 2019/002.

Lewis, L. 2020. Japan's corporate cash-hoarders have moment in the sun. Financial Times. Accessed from https://www.ft.com/content/247469ca-25b7-4bd8-8ac3-becf5530f15b.

Yoshikawa, T., \& McGuire, J. (2008). Change and continuity in Japanese corporate governance. Asia Pacific Journal of Management, 25(1), 5-24.

Publisher's Note Springer Nature remains neutral with regard to jurisdictional claims in published maps and institutional affiliations.

Toru Yoshikawa is a professor of strategic management at Lee Kong Chian School of Business, Singapore Management University. His main research interests include strategic and performance implications of corporate governance, board reforms and diversity, and corporate governance and strategy of family firms. His research articles have appeared in such academic journals as Strategic Management Journal, Academy of Management Journal, Organization Science, and Journal of Management.

Gavin Chua is a student at the School of Law, Singapore Management University. His research interest is Japanese corporate governance. 